\title{
Unraveling the Threads of History: Soviet-Era Monuments and Post-Soviet National Identity in Moscow
}

\author{
Revised for The Annals of the Association of American Geographers \\ August 2001
}

Benjamin Forest

Department of Geography

Dartmouth College

Fairchild Hall (HB 6017)

Hanover, NH 03755

Phone: (603) 646-0404

Fax: (603) 646-1601

E-mail: ben.forest@dartmouth.edu
Juliet Johnson

Department of Political Science

Loyola University Chicago

6525 N. Sheridan Road

Chicago, IL 60626

Phone: (773) 508-3059

Fax: (773) 508-3131

E-mail: jjohns@luc.edu

Both authors contributed equally to the research and writing of this paper. The research was funded by an Anne U. White Grant from the Association of American Geographers and a Regional Studies Grant from the Nelson A. Rockefeller Center at Dartmouth College. The authors would like to thank John Dunlop, Ron Suny, Karen Till, Michael Urban, participants in the Russian Studies Workshop at the University of Chicago, participants in the Collaborative Research Network Workshop on "Official and Vernacular Identifications in the Making of the Modern World" at Chiang Mai University (Thailand), and four anonymous reviewers for their thoughtful comments on earlier drafts. In addition, we especially thank Irina and Olga Kalina for their invaluable research assistance in Moscow. 
The wheel of history has turned 180 degrees as Moscow became Russia's first city to start sailing away from utopia and toward the nation's rebirth.... This means that a whole layer of national culture -the lost toponymy created by our ancestors throughout the centuries -has come back (Zhigailov 1996, 162).

The central memorial commemorating the Soviet victory over Nazism at Poklonnaia Gora in Moscow strikes one with visceral force. A huge dragon-like beast covered with swastikas, curled beneath a towering obelisk adorned by Nike, the goddess of victory, engages in mortal struggle with a statue of St. George on horseback (Figure 1). It forms the climactic center of the Victory Park (Park Pobedy) complex, which also contains a museum, three religious shrines, an expansive plaza, and other, smaller memorials. This imposing monument incorporates some of the most enduring symbols of evil, conflict, and victory in the Western cultural imagination. Indeed, from 1945 through the mid-1980s, World War II (which Russians call the Great Patriotic War) was perhaps the single most powerful element in the constitutive national narrative of the USSR. In short, memorials to this war were among the most potent sites for the construction of a Soviet national identity. Yet this monument site, originally chosen in 1957 under Khrushchev and planned during the Brezhnev era, was completed by the Moscow city government in 1995 as a site glorifying Russian national identity. The complex histories of Victory Park and other monument sites in post-Soviet Moscow raise a number of questions concerning both the nature of contemporary Russian nationalism, and the relationships among historical memory, national identity, and monuments more generally. 
Although monuments are powerful because they appear to be permanent markers of memory and history, they require both physical and symbolic maintenance, or what Nora $(1996,7)$ describes as "commemorative vigilance." In periods of normal politics, such commemorative vigilance typically occurs in undramatic, uncontroversial, and routine ways. Yet after the failed coup attempt of August 1991 and the subsequent breakup of the Soviet Union, Russia experienced a "critical juncture" in its history that fundamentally challenged every aspect of Russian identity - political, economic, and national. During this period Russia faced the immense task of forging a national identity distinct from the Soviet Union, and thus redefining itself as a nation rather than as the center of a territorial or ideological empire. Such critical junctures bring the politics of memory, and of monuments in particular, to the fore.

As such, the analysis of lieux de mémoire (places of memory) provides an ideal way to trace underlying continuities and discontinuities in national identity politics. ${ }^{1}$ Following Nora's (1996) pioneering study of French places of memory, geographers have produced a rich corpus of research on monuments, memorials, and national identity. We extend these works by emphasizing the importance of elite conflict over the (re)construction of national monuments at critical junctures in history.

Existing monuments and other places of memory can experience one of three possible fates during these rare and significant critical junctures: Co-opted/Glorified, Disavowed, or Contested. Co-opted/Glorified monuments are maintained or exulted further. Disavowed sites are literally or symbolically erased from the landscape either through active destruction or neglect by the state. Contested monuments remain the objects of political conflict, neither clearly glorified nor disavowed. The choices that 
political actors make about which existing sites are and are not "usable" - and the inclusiveness of the debate - reveals a great deal about changing official conceptions of national identity and the nation-building process. In the transition from Soviet to Russian nationalism, for example, the style and design of official monuments reflected much continuity between Russia and the USSR. Although the bulk of Victory Park was built after the fall of the Soviet Union, the memorial replicates the gigantic scale and overt symbolism characteristic of Soviet memorials. The story of post-Soviet Russian identity is, however, a complex one; Russians have not simply reproduced Soviet imagery. The addition of religious sites at Victory Park, for example, was not envisioned by its nominally atheist Soviet-era architects. In other cases, the meaning of Soviet monuments, memorials, and museums has been significantly altered by changing the composition of the sites or by moving monuments to different locations.

We argue that the physical transformation of places of memory during critical junctures reflects the struggle among political elites for the "symbolic capital" embodied in and represented by these sites (Bourdieu 1977, 1990). By co-opting, contesting, ignoring, or removing certain types of monuments, political elites engage in a symbolic dialogue with each other and with the public in an attempt to gain prestige, legitimacy, and influence. We develop this argument through an analysis of Soviet-era monument and memorial sites in contemporary Russia. In certain cases, competition for this symbolic capital encouraged elites to draw on representations of the nation already embedded in powerful existing monuments and memorials, transforming them from symbols of the Soviet Union into symbols of Russia. This elite competition also tended to exclude popular participation in the memorialization process, with civil society having 
little say in the ultimate fates of Soviet-era monument sites. These trends, in turn, contributed to the persistence of authoritarian and imperial representations of the Russian nation.

This article examines the critical juncture in Russian history from 1991 through 1999, during which rival political elites had the greatest opportunity to develop and attempt to impose their visions of Russian national identity on the symbolic landscape of the capital, Moscow. The material and data for this research, gathered principally during fieldwork in Moscow in July-August 1999 and July 2001, include Russian-language archival documents, newspaper articles, and books; field observation, museum exhibitions, and interviews; and a set of surveys administered to Russian-speaking visitors at selected monument sites. Our field research focused on three prominent places of memory in Moscow: Victory Park (Co-opted/Glorified), Lenin's Mausoleum (Contested); and the former Exhibition of the Achievements of the National Economy, or VDNKh (Disavowed). We also included a fourth site, Art Park (Park Isskustv), that displayed numerous Soviet-era statues outside the Central House of Artists.

In the remainder of this article, we first develop our argument about the role of monuments and symbolic capital in the formation and transformation of national identity. Following an examination of the political struggles over places of memory in Moscow, we analyze the interplay between elite and popular uses of the monuments, examining the extent to which popular reaction to the sites limits the ability of elites to manipulate their meaning and to control their symbolic capital. Finally, we discuss the Russian case in comparative perspective and explore the reasons behind the dearth of civic monuments in post-Soviet Russia. 


\section{National Identity and Symbolic Capital}

Our characterization of nationalism and national identity draws heavily on the constructivist school of nationalism (Anderson 1991, Gellner 1983, Hobsbawm 1990). This approach argues that nations and nationalism are relatively recent innovations tied to the rise of industrial capitalism, and that states and elites actively create national identity around important symbolic events and ideas. Common language and written texts play a particularly important role in the creation of national identity, both by facilitating the spread of nationalistic ideas and by creating a sense of solidarity. In general, nationalistic movements assert the existence of a unified political community, a nation, with a distinct historical narrative, cultural practices, language, ancestry, and territorial home. Although nationalists proclaim the ancient and continuous history of these characteristics, they are primarily contemporary inventions created in part to serve a particular political end -- the formation of a nation-state. Consequently, nations and nationalism typically have a contradictory relationship with history: National movements are of thoroughly modern origin, but their political coherence and social power rests on historical events and figures. To motivate political action and to create a sense of solidarity, nationalists selfconsciously create the myth of an ancient, timeless nation, and may even come to believe in it themselves.

Official memorials, monuments, and museums play a unique role in the creation of national identity because they reflect how political elites choose to represent the nation publicly. By erecting memorials in public space, states and interest groups attempt to define the historical figures that become national heroes and establish the historical incidents that become the formative events of a nation's identity (Atkinson and Cosgrove 
1998, Johnson 1995, Levinson 1998, Withers 1996). In short, they provide an elite representation of the imagined community of the nation. By honoring, profaning, and occasionally destroying these monuments the public may, however, take collective action to "speak back" to the state and redefine a nation's history and identity (Harvey 1979). Such popular responses may be in the form of routine participation, or in episodic and spontaneous action. Till (1999), for example, describes the conflicts among the four groups (politicians, victims, historical experts, and local citizens' groups) that negotiated over the creation and meaning of the redesigned Neue Wache memorial in Berlin. In contrast, the widespread, spontaneous physical destruction of the Berlin Wall and the occupation of Tiananmen Square in 1989 are some of the most dramatic examples of the public "speaking back" to the state (Hershkovitz 1993). Nonetheless, political elites generally have far greater power than the public to shape the physical and symbolic representation of national identity.

In order to move beyond the semiotics of individual monuments, our analysis draws on works that interpret landscapes as texts (Cosgrove 1998, Cosgrove and Daniels 1988, Duncan and Duncan 1988, Duncan 1990). This perspective suggests how the symbolic meanings of both physical and represented landscapes are deliberately manipulated to advance political interests, and how one may interpret landscapes as a reflection of those interests. ${ }^{2}$ Conflict can arise over both the design of individual monuments and their placement. Elites can alter the symbolic meaning of a site by modifying the particular design of a monument or memorial or by altering the pattern, arrangement, and relationships among different monuments. In both cases, they draw on particular symbolic vocabularies to express the meaning of monuments and monument 
sites. The imagery of good and evil used in the monuments at Victory Park is only one such example of this practice.

Why are places of memory used to create political communities, to raise national consciousness, and to act as proxies of power for elites and political factions; and why do conflicts over them escalate to such heights? Certain artifacts and events - such as dead bodies, gravesites, and burial ceremonies - have unique symbolic power because they invoke a sense of timelessness, awe, fear, and uncertainty (Verdery 1999, 23-53). The power to transcend time, to bring historical events and personalities into the present, makes such objects especially effective in mobilizing national movements. Yet not all monuments and memorials include bodies, or even commemorate lethal events. Moreover, as a practical matter they only modify land use in a limited area, and do not tangibly affect more standard measures of political power. To explain the apparently irrational significance of monuments and memorials, we develop Verdery's $(1999,33)$ observation that "symbolic capital" is essential to political transformations. The objectively disproportionate investment of time, money, and resources in monuments can be understood as conflicts over the accumulation, capture, and use of symbolic capital by political elites.

Bourdieu $(1977,1990)$ introduced the concept of symbolic capital in his analysis of social relationships in pre-capitalist, agrarian societies, although the idea has subsequently been applied more broadly to political conflicts and the built environment (Dovey 1992, Harrison 1995, McCann 1995). In essence, Bourdieu argues that relationships such as gift giving, marriage, and couvee labor cannot be properly understood as purely economic exchanges. Although such interactions have an economic 
component (e.g., an exchange of material, money, or capital), participants do not understand or treat them in terms of market logic. The "misrecognition" of economic exchanges is not due to ignorance or mistakes. Rather, this misrecognition plays a fundamental role both in maintaining the social order and (for individuals) in competition for social status and recognition. ${ }^{3}$ Social actors are fully aware of the economic consequences of their interactions and may nonetheless accept objective economic losses if their symbolic capital is at risk. In such cases, power within a family and community is derived and represented by the accumulation of status, honor, and prestige rather than by material wealth. The "exchange" of the symbolic capital not only disguises potentially disruptive economic relationships, but constitutes the most significant kind of value.

Bourdieu's principal concern is with interpersonal relationships and social status, although he ties symbolic capital closely to the web of practices, understandings, and structures (habitus) that sustains and constitutes particular societies. He also suggests, however, that symbolic capital is used by organized groups and institutions to advance what he terms "officialization":

Officialization is the process whereby the group (or those who dominate it) teaches itself and masks from itself its own truth, binds itself by a public profession which sanctions and imposes what it utters...[and contributes] to the maintenance of the social order from which it derives its power (Bourdieu 1990, 108).

Political groups with the greatest symbolic capital and those most adept at manipulating the rules and understandings governing the exchange of symbolic capital are more successful in advancing their agendas and projects. Like competition among individuals, 
these interests are not limited to economic gain, or in this case political power, but to the creation and maintenance of a particular worldview (i.e., the character of the Russian nation). In short, the accumulation of symbolic capital is not simply the means to an end (power), but is an end in itself.

Political struggles over symbolic capital become increasingly salient during critical junctures in a state's history, where dramatic circumstances call existing political, economic, and social arrangements into question and open a window of opportunity for fundamental institutional change (e.g., Krasner 1984, Collier 1991). Not only do critical junctures free political and economic institutions from their normal, inertia-bound, pathdependent relationships, as political scientists aver, but they create the possibility for significant redefinitions of national history and identity. Powerful political actors thus have a rare chance to impress their conceptions of the national character onto the public landscape, and in doing so assert their right to lead the nation and the state into the new era. These critical junctures are, however, both temporally and spatially limited. After a short period of political struggle and national self-reflection, institutions and identities crystallize again in an altered form, and become ever-more difficult to challenge. Similarly, the most intense and rapid change usually happens in a state's core cities, and especially in the capital. Elite-driven changes in the symbolic landscape will, therefore, tend to occur earlier and more radically in core cities, and less or occasionally not at all in smaller towns and rural areas far from the center. ${ }^{4}$ Moreover, while critical junctures create opportunities for fundamental change, the end results may not be so dramatic, and will vary across institutions and issue-areas (Johnson 2001). Creation of the new 
inevitably involves contingent recombination and incorporation of the old, in a process Stark (1998) has termed "bricolage” (cf Levi-Straus 1966).

The dismantling of the Soviet Union and its East European empire, the discrediting of the command economy, and the repudiation of the one-party communist state forced a profound rearrangement and reconceptualization of political, economic, and identity relationships throughout East Europe and Eurasia. As in earlier national movements, asserting national identity and cultivating a sense of the sacred by rewriting history and manipulating historical artifacts has been central to the legitimacy of postcommunist regimes (Verdery 1999, Suny 1999). This is true in a fairly straightforward way in former Soviet client states in East Europe, and perhaps more remarkably in former Soviet republics in the Caucasus and Central Asia such as Azerbaijan, Georgia, Kazakhstan, Turkmenistan, and Uzbekistan. This same phenomenon is at work in postSoviet Russia as well, albeit with a nationalism that has a more complex relationship to the Soviet period.

For centuries, Russia's national identity had rested on its position at the center of a geographical and ideological empire, a view that Soviet leaders easily adopted and adapted after the October Revolution. As a result, Russian and Soviet identities were closely intertwined. The conceptual relationship between the two entities became increasingly complex, however, during the political maneuvers leading to the disintegration of the USSR. Before the late 1980s, the Soviet Union maintained "structural asymmetries" with the Russian Soviet Federal Socialist Republic (RSFSR) designed to suppress a sense of Russian national identity separate from the USSR (Dunlop 1993, Kaiser 1994). Although the USSR's center of power was clearly in Russia, 
unlike the other Soviet republics the RSFSR did not have separate, republic-level social, cultural, and scientific institutions until Yeltsin's election as chairman of the RSFSR's Supreme Soviet in 1990. Indeed, challenging the conflation of Russian and Soviet identity became an increasingly important part of Yeltsin's bid for power against Gorbachev and the central government.

Yeltsin was ultimately successful in achieving Russian sovereignty, and along with it, the disintegration of the USSR. As Graham Smith $(1999,8)$ observes, however, "because Russians have throughout recent history been used to identifying with such a larger homeland, either in the form of the Tsarist empire or the Soviet Union, many have found it difficult to adjust to the loss of that homeland. Consequently, the geographical imagination of what and wherein lies Russia's homeland becomes far less clear-cut." The demoralizing, destabilizing economic dislocation and loss of international status that accompanied the transformation further complicated the issue of identity for Russians. Therefore, after the USSR's dissolution destroyed the geographical basis for Soviet identity, Russia engaged in an intensive search for a "new," post-Soviet identity and for a "usable" past.

During this critical juncture, Russians considered a wide range of possible identities incorporating various combinations of ethnic, imperial, and civic nationalisms. The first, or ethnic ideal, sees Russia primarily as an exclusive political community defined by language, religion, and cultural heritage. This ethnic nationalism harks back to the Slavophile view of Russians (or the Russian “soul”) as neither Western nor Asian, but as uniquely spiritual, communally oriented, and intimately connected to the Russian landscape. The second, or imperial ideal, views Russia as a great power and as the center 
(or as the appropriate center) of a larger regional empire. ${ }^{5}$ This imperial identity is not necessarily defined by physical expansion, but by political, economic, or ideological influence, and often incorporates a more pro-Soviet viewpoint. The third, or civic ideal, inclusively defines Russian identity around democratic institutions, the rule of law (constitutionalism), and the populist-democratic uprising against the Soviet Union. ${ }^{6}$ This ideal has its roots in the writings and deeds of Russia's so-called Westernizers, from Peter the Great forward, who believed that Russia's true character is "modern" and European.

Nationalism remains a significant force in contemporary Russian politics, particularly as the country tries to (re)establish a distinct, but powerful place in the global political order. In the early 1990s, Russians seemed to decisively reject the unity of Russian and Soviet identity (Dunlop 1993). Yet the relatively civic and democratic rhetoric of this early period did not provide a successful new model for Russian nationalism. As an analysis of political struggles over Soviet-era places of memory shows, ethnic and imperial ideals remained prominent themes in Russian national narratives, while certain aspects of Soviet identity re-emerged in the 1990s to bolster various versions of Russian national identity.

\section{Building Symbolic Capital in Post-Soviet Moscow}

Monuments, memorials, museums, and place names have traditionally played a central role in defining Russian national identity. Indeed, many of the first actions of Russia's new governments after the revolutions of both 1917 and 1991 involved renaming places and revising monuments, suggesting that the control over symbolic public spaces 
is exceptionally important in Russian politics. In Russia, competition over Soviet-era monuments and memorials represented competition for the usable symbolic capital (honor, prestige, glory, sacrifice, etc.) embodied in these sites. As in Soviet times, political elites played the key role in the contentious process of memorializing and renaming because they retained control over the resources required to build and alter public monuments. ${ }^{7}$ In this context, one may extend the analogy between symbolic and economic capital further. As a number of recent works have documented, a relatively small number of politically influential individuals acquired the bulk of state resources during the transformation from the command economy to the market system (Cohen 2000, Johnson 2000, Reddaway and Glinski 1999, Solnick 1998). Russia became a capitalist economy, but one in which the disparities of the Soviet system were exaggerated, and where a small group obtained the lion's share of wealth. Likewise, former Soviet political elites often retained enormous political power in Russia's quasidemocratic system. Competition for symbolic capital thus involves principally these political elites because both economic and symbolic resources are concentrated in this small group. Even during the most turbulent periods of 1991, political elites (albeit local ones) exerted tremendous influence over even relatively spontaneous actions taken against monuments.

Russian politicians have used this power to attempt to "capture" monument sites (i.e., to assert the right to determine how sites will be used and changed) and to spark debates over monument sites as a means to engage in larger ideological and political struggles. This process has been particularly complicated because the relative continuity of political elites during the post-Soviet transformation has meant that while Russian 
elites may have been uncomfortable with many aspects of Soviet identity, they often preferred to reinterpret rather than to erase or ridicule this past. Physical control over Soviet-era sites was not just a tangible manifestation of practical political power, but was quite literally an attempt to control Russian national identity.

We focus on the political struggle over symbolic sites in Moscow for two reasons. First, central Moscow is densely packed with a wide variety of nationally significant Tsarist-era, Soviet, and post-Soviet places of memory. Conflict over the design of individual monuments can occur regardless of location, but conflict over placement is especially acute in symbolically dense landscapes where even minor physical changes alter the meaning of the site as a whole, and where new monuments are placed in specific relationship to existing memorials. ${ }^{8}$ It is hardly accidental, for example, that its designers placed Victory Park beside the Triumphal Arch celebrating the Russian victory over Napoleon. Red Square and adjacent areas have even greater symbolic density, because this relatively small territory encompasses sites such as the Kremlin, the Place of Execution (Lobnoe mesto), Lenin's Mausoleum, and the Tomb of the Unknown Soldier (Mogila Neizvestnogo soldata). Therefore, recent additions such as an oversized equestrian statue of Field Marshall Zhukov (the general who led the Soviet army from Moscow to Berlin during the Great Patriotic War) and the reconstructed Kazan cathedral (Kazanskii sobor) have meaning and repercussions for the other sites in the area as well.

Second, Moscow is both Russia's largest city and the seat of the Russian government. As such, battles for control over sites among city officials, the central government, the State Duma (Russia's lower house of parliament), and various political parties have national resonance and relevance. Places of memory in national capitals 
reflect the most prominent elite conceptions of the nation, and are most vulnerable to change during critical junctures. While myriad groups and individuals had a strong interest in the fate of Moscow's monuments, memorials, and museums, far fewer had the political power to affect them physically in a systematic way. From 1991 through 1999 there were three primary actors in this drama: Moscow mayor Yurii Luzhkov and the Moscow city government, the Communist Party of Russia (KPRF), and the administration of Russian president Boris Yeltsin.

Luzhkov actively wielded and amassed symbolic capital in the city in order to define himself as a populist, nationalist, and anti-Soviet leader, and to promote an image of Russia as a great military and spiritual power bridging the gap between East and West. Luzhkov, in his efforts to become a more nationally known politician before the December 1999 State Duma elections, also began to use ethnic and imperial nationalist rhetoric to appeal to the broader Russian public. For example, he presented himself as a strong supporter of the rights of ethnic Russians living in the "near abroad," and suggested that the Crimea be returned to Russia from Ukraine. Throughout his tenure, Luzhkov condemned the Soviet treatment of Moscow as "barbarous destruction" and trumpeted his extensive and high-profile restructuring of Moscow's historical landmarks as evidence of his commitment to a more traditional vision of the Russian nation (Luzhkov 1996; Poliatykin 1996; Miliutenko 1999). As Luzhkov himself put it, “Our 'revolution' is no revolution, but only a slow return to the normal order of things" (Luzhkov 1996, 193). Moreover, Luzhkov played an instrumental role in encouraging the new Russian economic elite to help finance his construction efforts, offering them both 
lucrative business relationships with the city and an opportunity to polish their public images in implicit exchange for their support.

In contrast, the KPRF (the leading party in the State Duma) attempted to rehabilitate parts of the Soviet past through preserving and redefining certain Soviet-era monument sites. Although the KPRF admitted that the Communist Party of the Soviet Union (CPSU) had made mistakes, it emphasized that the Russian Revolution, the Soviet Union's glorious victory in the Great Patriotic War, and the USSR's communist-led industrial modernization had transformed the backwards Russian imperial state into one of the world's two greatest powers. Rather than jettisoning that legacy, the KPRF and its supporters preferred to preserve certain symbols of the Soviet past as a way in which to promote their political vision of a socialist-nationalist Russian identity. They did not have the power to erect new monuments in Luzhkov's anti-Soviet Moscow, but they battled fiercely to preserve many of the old ones.

Finally, Russian president Boris Yeltsin presented himself simultaneously as a Western-oriented democrat and as a Russian nationalist. Yeltsin's nationalism aimed more at engendering pride in the Russian state rather than in Russians as an ethnic group (for example, using the term rossiiskii rather than russkii to talk about the nation). As a result, he saw no inherent conflict between these two conceptions of identity and attempted to use his control over symbolic capital to promote versions of both. At the same time, Yeltsin attempted to downplay and reinterpret Russia's Soviet past. This proved particularly important and tricky, because although Yeltsin wanted to be remembered as the man who had freed Russia from Soviet power, during Soviet times he had swiftly risen through the ranks of the Communist Party and had served as a candidate 
member of the Soviet Politburo. Moreover, he admitted in 1990 that he "had until recently ... thought of himself as a 'Soviet' and not a Russian” (Dunlop 1993, 55). In a telling example of this complexity, in Soviet times Sverdlovsk party boss Yeltsin carried out the physical destruction of the historic Ipatiev House, where the Bolsheviks murdered Tsar Nicholas II and his family in 1918. Yet Russian president Yeltsin actively led the effort to bring the royal family's remains back to St. Petersburg and give them a formal Russian Orthodox burial in 1998.

In many ways, Yeltsin's own multiple, changing, and often confused conceptions of identity mirrored a nationwide disorientation. The process of creating a new Russian national identity was so central, and so troublesome, that in July 1996 Yeltsin announced a year-long competition to discover a new Russian "national idea," with a ten million ruble prize to be awarded the victor. As Yeltsin observed, "In Russian history of the 20th century there were various periods -- monarchism, totalitarianism, perestroika, and finally a democratic path of development. Each stage had its ideology. . . But now, we have none" (in Henry 1996). Tellingly, this competition had no winner. With Russian national identity up for grabs, these politicians' often conflicting efforts to (re)mold monument sites in Moscow reflected more than their broader disagreements about Russian national identity. Such endeavors represented a relatively cheap and potent way in which to signal their political intentions and to promote their preferred visions of Russia to a Russian population suffering from a severe post-Soviet identity crisis.

Broadly speaking, Soviet-era monuments can be placed into one of three logical categories, Co-opted/Glorified, Contested, or Disavowed, with their status determined by the relative "commemorative vigilance" they have enjoyed since 1991. Consequently, the 
fate of monuments reflects the different political status - and thus the differing political

uses (and usefulness) - of the symbolic capital associated with sites of that type (Table 1).

While we concentrate primarily on Soviet-era sites because their post-Soviet fates

highlight the most controversial and telling aspects of identity formation in Russia, the analysis can be extended to pre-Soviet sites as well.

Table 1: Political Status of Soviet-Era "Places of Memory"

\begin{tabular}{||l|l|l||}
\hline Co-opted / Glorified & Contested & Disavowed \\
\hline WWII (Great Patriotic War) & Russian Revolution & CPSU \\
Russian Orthodoxy & Lenin and other Bolshevik leaders & Soviet economy \\
Pre-1917 Russian history/culture & & \\
\hline
\end{tabular}

\section{Co-opted/Glorified Sites: The Past as Prologue}

The first category, Co-opted/Glorified, contains those sites that Russian political leaders have chosen to expend considerable resources on redefining and re-incorporating into prominent public view since 1991. These sites, commemorating the Great Patriotic War, the Russian Orthodox Church, and Tsarist-era Russian history and culture, emphasize the "best" of Russia's ethnic and imperial past while downplaying Russia's troubled Soviet-era domestic political heritage. Therefore, while the different political factions typically agreed on the importance of these sites, they vied with each other to gain physical control over them and to become publicly associated with them.

The glorification of selected Tsarist-era sites reflects the desire of many nationalistic politicians to co-opt and redefine post-Soviet Russian national identity by appealing to deeply held beliefs about Russia's unique and important spiritual and cultural heritage. For example, the Russian government paid for reopening and reconstructing the Tretiakov Gallery, which showcases the best-known Russian painters 
and iconographers. Similarly, political groups as diverse as Luzhkov's political party Otchestvo (Fatherland), the KPRF, and eccentric nationalist Vladimir Zhirinovskii's Liberal-Democratic Party of Russia engaged in elaborate public celebrations on the $200^{\text {th }}$ birthday of Russia's beloved poet Aleksandr Pushkin. Each group used the occasion to present itself as a superior defender of Russian language and culture (Shulyakovskaya 1999). ${ }^{9}$

Rebuilding prominent Russian Orthodox churches and monasteries represented an even more overtly political act, because it gave an explicit symbolic slap to Soviet power by physically replacing that which the Soviet government had once wiped away. Moreover, it glorified the Russian nation by reviving the Church's traditional emphasis on spiritual triumphalism, which depicted Holy Russia as the center of a religious empire. Yeltsin and other members of the Russian government flaunted their (in most cases newfound) religiosity by supporting reconstruction efforts, while the KPRF preferred to at most ignore these efforts. But it was Luzhkov, as an avowed anti-communist and Russian nationalist, who took the lead in politically exploiting Moscow's religious sites. Completing plans made by the previous administration, the Moscow city government rebuilt the Kazan Cathedral on Red Square in 1993. This represented the first public restoration of a completely destroyed church in Moscow (the revered church was dynamited in 1936, under Stalin). This, however, was only a minor prelude to Luzhkov's extravagant reconstruction of the Cathedral of Christ the Savior (Khram Khrista Spasitelia). Although Stalin had destroyed the cathedral in order to erect a grandiose Palace of Soviets on its site, he never managed to build the palace, and a decidedly mundane swimming pool occupied the site for the rest of the Soviet era (Sidorov 2000). 
Luzhkov made its reconstruction a centerpiece of his Moscow revitalization plans, officially opening the cathedral during the city's 1997 celebration of Moscow's $850^{\text {th }}$ anniversary. ${ }^{10}$

As arguably the most tragic and glorious moment of the Soviet era, the Great Patriotic War and its associated memorial sites represent the most politically complex ones in this category. Although what Tumarkin (1994) calls the "Cult of World War II" declined precipitously during the Gorbachev years as glasnost-inspired revelations undermined many Soviet myths surrounding the war, Russian politicians used memorialization and pageantry to revive and reinterpret the war's history in a much more positive light after 1991. In Moscow, the Tomb of the Unknown Soldier outside the Kremlin wall and Victory Park at Poklonnaia Gora are the most notable of these sites. The Russian government added an honor guard to the former site (in pointed contrast to the earlier removal of the honor guard at Lenin's Mausoleum), while Luzhkov erected a prominent statue of Marshall Zhukov around the corner in Manezh Square in preparation for the May 1995 celebration of the 50th anniversary of the war's end. All three primary political actors in Moscow rhetorically "glorified" the sites commemorating the war and attempted to co-opt them for political purposes. However, while Luzhkov and Yeltsin used the sites to redefine the war primarily as a great Russian victory (won in spite of Stalin and the CPSU), the KPRF emphasized that the sites commemorate a Soviet victory. In doing so, the Communists attempted to use the symbolic capital of these sites to rehabilitate the Soviet past and revive the memory of a larger, more powerful Union. This competition, redefinition, and glorification of the Great Patriotic War was most evident at Victory Park (Figure 2). A huge complex, Victory Park spans 135 
hectares. On February 23, 1958, the Soviet government first inaugurated the site with a modest obelisk stating that "a memorial to the victory of the Soviet people in the Great Patriotic War, 1941-1945, will be erected here” (Krasnaia zvezda 1958) ${ }^{11}$ In 1961 ground was broken for the park, and later the USSR Ministry of Culture decided to build a museum on the site. However, construction ceased completely under Gorbachev due to a lack of funds, a growing uneasiness about the Soviet myths surrounding WWII, and political demonstrations demanding that the museum be torn down and the Hill itself (razed years earlier) be rebuilt. As Tumarkin observed in May 1990, on the $45^{\text {th }}$ anniversary of the victory, "the cult [of WWII] was manifestly finished as an institution," (Tumarkin 1994, 190).

Yet in 1993, Luzhkov took a personal interest in the site, and restarted the construction process to great fanfare (Kinzhalov 1999). Not only did the Moscow city government financially support the construction efforts, but Luzhkov himself oversaw the project's rapid completion and participated (some might say meddled) in the final design of the park, ending the controversy over (and public participation in) the design of the central monument. As a coffee-table book produced for Moscow's $850^{\text {th }}$ anniversary celebration boasted:

In just a few years the city repaid its longstanding debt to the veterans of the Great Patriotic War, which CPSU leaders Khrushchev, Brezhnev, and Gorbachev failed to do. A memorial in honor of the victors was constructed on Poklonnaia Hill. A bronze obelisk-bayonet rises 141.8 meters high, commemorating the 1,418 days of war. Mayor 
Yurii Luzhkov drew the sketch of the bayonet in the studio of sculptor Zurab Tsereteli on March 27, 1994 (Zhigailov 1996, 164).

Yeltsin, loathe to allow Luzhkov to gain all of the credit, regularly appeared at the site as well. He presided over opening ceremonies for the museum's building on Victory Day (May 9) 1993, as well as at the official opening of the full complex on Victory Day 1995. Indeed, the cult's re-emergence on the elite level became evident during the 1995 commemoration of the 50th anniversary of the victory. The Moscow city government, the Russian government, and the KPRF all held massive dueling celebrations, blanketing the city in military banners, posters, and other paraphernalia.

However, given the unsavory revelations of the Gorbachev era, Luzhkov and Yeltsin could only tap the symbolic capital preserved in the Victory Park complex by redefining the Great Patriotic War as a victory for the Russian people rather than for the Soviet Union. As Yeltsin remarked in a speech on Victory Day 1999, "the holiday of victory unites all Russians, independent of persuasion or biases. Then and now, the strength of Russia lies in national concord and unity" (quoted in Moscow Times 1999). In emphasizing the Russian character of Victory Day, the most controversial parts of the Soviet role in WWII could be swept aside (such as Stalin's pact with Hitler, the forcible incorporation of the Baltic states, the deportations of non-Russian peoples, and the devastation of Ukraine and Belarus). This left a neater, less ambiguous history with which to work. 
At Victory Park, this redefinition was accomplished, first, by adding prominent religious (i.e., anti-Soviet) elements to the site. Not only did St. George and two angels grace the central monument, but Luzhkov ordered the construction of a Russian Orthodox church on the site. The magnificent Cathedral of St. George, built in 1994 and consecrated on May 6, 1995, occupies a central position on the complex's main plaza. In addition, a few years later a mosque and synagogue were added to the rear of the park. The mosque was completed in 1997, constructed through a joint initiative of the Moscow city government and the Ecclesiastical Board of Moslems of the Central European Region of Russia. The Russian Jewish Congress funded the synagogue, which opened in September 1998. Both Yeltsin and Luzhkov spoke at the dedication (Pestereva 1998).

Second, the re-constructors removed many of the originally planned Soviet symbols from the park's blueprints, replacing them with Russian symbols. ${ }^{12}$ For example, a national contest held in the 1980s had determined that the central monument would be made of red granite, featuring an enormous curling banner topped with a star (Russia Journal 1999). When Luzhkov restarted the construction, however, he gave the commission to his favorite sculptor, the controversial Zurab Tsereteli. Tsereteli's monument downplayed the Soviet symbolism while incorporating St. George and the dragon, the symbol of the city of Moscow, at the center. In another case, the Moscow city government erected a statue group called "To the Defenders of the Russian Land" (Zashchitnikam zemli rossiiskii) on Kutuzovskii Prospect, anchoring the side of the park opposite the Triumphal Arch. This statue group depicts three Russian soldiers - ancient, Tsarist, and modern - standing at attention, while bright yellow flowers spell out Rus' below (Figure 3). According to one of the Park's official brochures, "The sculpture group 
'To the Defenders of the Russian Land' embodies the realization of our national community, the preservation and defense of which is dearer than life." The brochure continues on in this vein, observing that "There are places in Russia where, upon visiting, a Russian (russkii) person cannot remain unmoved. One of these is the Memorial of Victory on Poklonnaia gora ... [which reminds one] of the striking manifestation of the sublime spirit of unity of the Russian people." But what is truly striking is that this official brochure fails to mention the USSR at all. Through this redefinition, Russian political elites obtained the substantial symbolic capital tied into this Soviet-era site by strategically ellipsing the past.

\section{Contested Sites: The Past as Problem}

The second category, Contested, contains Soviet-era monuments that continued to be a source of major conflict among the various political groups in Moscow espousing contrasting ideas of national identity. Monuments in this category tended to be those commemorating Lenin and the Russian Revolution, as opposed to the Soviet state itself. In other words, they reflected the history and ideals of the Revolution rather than the oppressive institutions of Soviet rule.

Lenin's Mausoleum on Red Square not only represented the archetypal "contested" memorial, but his body was the single most sacred artifact for Russian

Communists (Figure 4). The communist State Duma speaker Gennadii Seleznev spoke of the body in unabashedly reverential terms: "There is a mass of people for whom the name Lenin is a religion, just like God is a religion for Orthodox Christians" (Agence France Presse 1999). For many non-communists, however, Lenin's body was the mummified 
personification of the Soviet past, and a constant reminder of the Soviet Union's quasireligious veneration of its doggedly secular leadership. As a result, after the failed coup in August 1991, politicians began an ongoing, fierce debate over what to do with the imposing tomb and embalmed body of the leader of the October Revolution.

After his death in 1924, Lenin's body was preserved and placed in a temporary wooden crypt on Red Square for the funeral and public viewing. This building was soon replaced by a larger, more elaborate, wooden structure, and then in 1930, under the direction of Stalin, by a stone mausoleum (Tumarkin 1997, 189-206). Until the late 1980s, the site continued to attract thousands of visitors each day, visitors who often waited in line for hours even in the depths of winter. Although the Soviets officially characterized the preservation of the body as a scientific experiment, the act mirrored the old Russian tradition of preserving the bodies of Tsars. ${ }^{13}$ It also tapped the Orthodox religious belief that saints' bodies were incorruptible after death (see Tumarkin 1997). After Stalin's death, his body lay next to Lenin's for eight years until Khrushchev ordered it secretly removed overnight in 1961 as part of his de-Stalinization campaign.

After Yeltsin came to power, he made repeated threats to bury Lenin's remains. Shortly before we began our fieldwork, he renewed these threats, stating that the burial of Lenin and Tsar Nicolas II were two key goals for his final term in office (Agence France Presse 1999). Like many actual reburials, these threats carried potent political symbolism. By burying Lenin's corporeal body, Russian leaders could bury “the invisible body 'politic' that was immortal, infallible, and capable of 'absolute perfection'” (Bonnell 1997, 149). These repeated declarations also exacerbated the already high tensions among Russia's political elite during this period and inspired renewed popular interest. 
Long lines formed once again outside the mausoleum on Red Square during visiting hours, and elderly Communist demonstrators brandishing placards reading "Hands Off Lenin!" kept angry watch over the body. KPRF leader Gennadii Ziuganov warned that his party had a plan for "emergency measures" if Yeltsin attempted to remove the remains.

The burial controversy was only the most dramatic manifestation of the longrunning conflict over Lenin's body and the mausoleum itself. The cost of maintaining the site, for example, was an ongoing source of bickering among communists and noncommunists in the Duma after Yeltsin cut off funding for preserving Lenin's body in 1993 (Yablokova 1998). Since then the Lenin Mausoleum Charitable Foundation has paid for the preservation of the body itself, while the Russian government has paid for the upkeep of the structure (Hearst 1999). Like this financial division, the physical separation of the body and the mausoleum may ultimately provide a political compromise whereby Lenin would be reburied, but the mausoleum itself would remain in place.

While Lenin's Mausoleum was the best-known contested site, there were many others. For example, the former Museum of the Revolution (Muzei Revolutsii) on Tverskaia Street lived on in altered form. While CPSU-controlled Soviet history museums in Moscow were uniformly and quickly closed down, the Museum of the Revolution, administered by the Soviet Ministry of Culture, re-emerged as the Museum of the Contemporary History of Russia (Muzei Sovremennoi Istorii Rossii). Although it retained its unparalleled collection of revolutionary memorabilia, in order to ensure the museum's survival its curators added high-quality exhibitions on political life in the postSoviet period and redefined it as a Russian - not Soviet - museum. However, the 
museum's entries in the Moscow Encyclopedia (a book financed by the city of Moscow for the $850^{\text {th }}$ anniversary celebration) revealed the Luzhkov administration's continuing discomfort over the site. The most prominent entry identifies the building not as a museum, but as the English Club, a reference to its Tsarist-era identity.

The fate of Lenin statues and of streets, parks, and buildings named after Lenin or the October Revolution in Moscow reflected a similar political discomfort and uncertainty. While many Lenin statues were pulled down and places renamed, a significant number of others remained unchanged. For example, prominent statues of Lenin still stood in October Square (Oktiabr'skaia ploshad') and at the former VDNKh, while the statue of a thoughtful Lenin that had once graced the Kremlin gardens quietly vanished. Likewise, the Lenin Hills (Leninskyi gory) reverted to the Sparrow Hills (Vorob'evy gory) and the Lenin Library became the Russian State Library, but other names such as Lenin Prospect (Leninskii prospekt), the Leningrad Highway (Leningradskoe shosse), October Square, and the Square of the Revolution (ploshad' revoliutsii) remained. Incongruously, the Revolution Square metro station still symbolically called citizens to arms with its numerous dramatic statues of revolutionary workers, soldiers, and peasants. The "contested" nature of such sites meant that each decision to rename, remove, or redefine one was made and fought over individually, with no single political group able to completely enforce its (re)interpretation of Lenin. Moreover, the partial de-Leninization of Moscow physically reflected Lenin's ambiguous symbolic legacy for Russians. 


\section{Disavowed Sites: The Past as Pariah}

The third category, Disavowed, encompasses those monuments that were removed, closed, or so changed that their original symbolism was eradicated. This category included monuments to the two defining institutions of the discredited Soviet state itself - the Communist Party of the Soviet Union (CPSU) and the command economy. No mainstream contemporary political forces saw an advantage in incorporating the blatant Soviet symbolism of these sites into their Russian nationbuilding repertoires. As a result, the sites were either simply ignored or became subject to massive redefinition and reconstruction.

Indeed, many sites in this category did not survive at all. For example, a Yeltsin decree of November 1993 permanently closed the Central Lenin Museum, administered directly by the Communist Party and commemorating the Party's history from the Revolution through the Gorbachev era. Although named for Lenin, in Soviet times the museum "became a powerful center of propaganda for the ideas of Marxism-Leninism, and for the formation of intellectual and emotional fidelity to the communist party's policy and activity" (Van der Heijden 1998, 39). Unreformed communists occasionally demonstrated on its steps, but the KPRF refused to make the museum's fate a political issue. Indeed, MMM - one of the most notorious Russian pyramid (Ponzi) schemes - kept offices on the disgraced museum's top floor.

The Exhibition of the Achievements of the National Economy (VDNKh) represents the most interesting site in this category (Figure 5). In Soviet times, VDNKh (originally founded in 1939 as the All-Union Agricultural Exhibition, or VSKhV) was the most important public showplace for Soviet economic ideology. When the exhibition first 
became permanent its pavilions honored the economic accomplishments of individual Soviet republics, with the golden "Fountain of the Friendship of Peoples" as its centerpiece. Under Khrushchev, the focus shifted from individual republics (which lost their pavilions completely) to economic sectors such as metallurgy, medicine, coal mining, and transportation. In its final form, this vast theme park dedicated to the glorification of the command economy included 72 exhibition pavilions, from the Atomic Energy Pavilion to the Pavilion of Large Horned Livestock. Located on 238 hectares on the far northeast side of Moscow, the park attracted thousands of visitors to its economic exhibitions each year. According to one of its Soviet hagiographers, "VDNKh is the Soviet Union in miniature" (Il'in 1986).

Its turbulent and ironic post-Soviet history as a profitable commercial center and open-air flea market epitomized Russia's uneasy adaptation to capitalism. As one of the women who had worked for years in the Metallurgy Pavilion bluntly told us, "Everything changed immediately in 1991." VDNKh no longer received government financing, and its dwindling cash resources and prestige led travelling exhibitions to go elsewhere. Indeed, in an interview in 1990, VDNKh's primary architect already spoke despairingly about the unkempt, almost abandoned grounds (Glushchenko 1990). Yeltsin himself changed VDNKh's name to the generic VVTs (All-Russian Exhibition Center) in June 1992 by decree. In 1999, director Vasilii Shupyro could still complain that "Architectural monuments remain here with us, no more and no less than 46. But for their upkeep we don't receive a single kopeck from the state" (quoted in Korotkaia 1999). Most notably, the famous statue "The Worker and the Collective Farm Girl” (Rabochii i kolkhoznitsa) 
outside and to the right of the main entrance stood neglected, its surroundings weedy and its reflecting pool empty.

However, although the site's symbolic capital had rapidly depreciated, its fixed capital remained. The pavilion workers, left on their own, began to rent space in their now-bare pavilions to small traders and merchants. VVTs, with its vast array of pavilions and its own metro stop (still called VDNKh), soon became a bizarre sort of mall. A children's play center with a Jungle Book theme appeared in the Chemistry Pavilion, while the Atomic Energy Pavilion boasted an "information technology center" with computers, faxes, printers, and xerox services. At VVTs, Russians could buy everything from home electronics to jewelry to cars. Later, the complex allowed an amusement park to move in. The Soviet-era names on the pavilions began to come down, replaced by numbers. In the absence of state funding the leadership of VVTs devised a strategic plan in 1999 to attempt to lure more large-scale commercial exhibitions to the site. This strategic plan listed Ekspotsentr and Rosstroiekspo exhibition centers as the main competition for VVTs, and discussed the need to improve the VVTs "image" (Sovet directorov 1999). VVTs even threw itself a large $60^{\text {th }}$ Anniversary celebration in the summer of 1999, with special exhibitions on its history and on Russian industry and agriculture. According to Shupyro, VVTs decided to hold this celebration because "we want famous people to come here and to talk with us about our problems," (Borodina 1999). Although anachronisms like a large Lenin statue and a rocket in front of the former Cosmos Pavilion remained, the original meaning of the site had been stripped. As a Western reporter noted in 1994, "The panoply of imported goods prompted one foreign visitor to dub VDNKh 'the Exhibition of the Achievements of the Peoples of Germany, 
Japan, and Korea"' (Barnard 1994). While VDNKh had celebrated Soviet citizens as producers, VVTs embraced Russian citizens as consumers.

\section{Art Park: The Past as Past}

Our fourth study site, Art Park, illustrates how sites could shift between categories as the political winds shifted towards more or less pro-Soviet views of Russian history. Pictures of Russians physically tearing down statues of Soviet leaders in 1991 provided some of the most enduring images of the USSR's collapse. The subsequent treatment of such statues shows how the meaning of monuments and memorials can change by changing their physical context, or spatial framing. These Soviet icons moved from public spaces representing national identity, to a literal trash heap, to a tourist attraction, and finally to a historical and artistic display.

Images and accounts of crowds toppling the statue of secret police founder Feliks Dzerzhinskii from the front of KGB headquarters in Lubianka Square on August 22, 1991, suggest that it was a spontaneous act against the most feared and hated icon of Soviet repression. The description of the incident in Luzhkov's autobiography argues, however, that he (or at least municipal authorities) played a significant role in this event (Luzhkov 1996, 272-276). According to his account, the crowd was unable to knock over the massive bronze figure, so the prefect of the central Moscow region, Alexander Muzykantskii, shouted over a megaphone that "the decision to remove the monument has already been made! The statue of Dzerzhinskii absolutely will be removed! Now! Quickly! Three powerful cranes are already on the way! It is simply necessary to wait." 
After the cranes arrived and took down the statue, they were used to pull down nearby statues of Soviet leaders Kalinin and Sverdlov. ${ }^{14}$

While Luzhkov had an incentive to exaggerate his own part in this process, Moscow city officials certainly played a key role in the removal and relocation of local monuments. After their removal, several Soviet-era monuments were placed haphazardly in a field behind the Central House of Artists. (Figure 6). Luzhkov describes the creation of this park as “... an excellent thought. It called into being a longtime dream: to gather together all of the bronze and granite Soviet leaders, heroes, farmers, to enclose them in a fence, and allow children to play there." Many of the statues were physically damaged or sprayed with paint either during or after the moving process. The treatment of these statues was perhaps the most literal and spontaneous deconstruction of the Soviet state by the Russian public, and represented a literal attempt to "trash" Soviet history. Other than actual physical destruction, this was perhaps the most radical form of disavowal that a monument could suffer. Yet these monuments did not disappear from public consciousness. After abandonment in the park the jumble of Soviet icons acquired such kitsch-value that the area became a popular tourist destination.

In 1996, the Moscow city government formalized the display by restoring the statues, installing small plaques identifying the figures, and naming the area Art Park (sometimes also referred to as "The Park of Totalitarian Art"). The new park was placed under the jurisdiction of Muzeon, a subsidiary of the Government of Moscow's Committee on Culture, and became a display area for contemporary artistic works. By the summer of 1999, former Soviet leaders shared the park with a rose garden, abstract religious art, and numerous busts. These busts depicted Russian cultural icons such as 
Pushkin, Gogol, Gorky, Yasenin, and Lomonosov; Russian political and military leaders like Peter the Great and Kutuzov; and more startlingly, foreign writers, artists, and scientists, including Einstein, Shakespeare, van Cliburn - and Gandhi! Part of the grounds was also converted to an outdoor workshop for sculptors associated with the Central House of Artists.

The most important Soviet-era statues had plaques identifying the subject, artist, material used, and where the piece had been displayed. After this description, the plaques attached to the statues ended with a depoliticizing disclaimer: "It has historical and artistic value. The monument is in the memorializing style of political-ideological designs of the Soviet period. Protected by the state." Guides also conducted tours of the park and were careful to describe the Soviet statues in similar terms. Characterizing these statues solely in historical and artistic terms intended to drain them of their political significance by politically decontextualizing the works and emphasizing their alleged artistic value. Indeed, except for the statue of Stalin, the pieces were placed haphazardly and the descriptions never referred to more than a single statue. ${ }^{15}$ Although such displays are more respectful than a trash-heap, most statues in the park were effectively stripped of their political significance. Indeed, our survey revealed that almost all visitors used Art Park simply as the nearest, most convenient park. Such depoliticization illustrates the Moscow government's success in removing the symbolic significance once embodied in these works.

The statue of Dzerzhinskii became a partial exception to the decontextualization strategy when it shifted from the disavowed to contested category in 1998 (Figure 7). On December 2, the State Duma approved a resolution asking that the Moscow city 
government restore the statue to its former place on Lubianka Square (Tolstikhina 1998).

Although the resolution, sponsored by the Agrarian and Communist parties, advocated the return "as a symbol of the fight against crime," the broader symbolic meaning was clear: the Soviet past should be restored to its rightful place. Both the Moscow city Duma and Luzhkov ignored the resolution, characterizing it as a violation of local control without addressing the symbolic significance of Dzerzhinskii: "What monument will stand on Lubianka may be decided only by Muscovites" (Yablokova 1998). The statue remained in Art Park, but as a contested monument. In July 2000 the KPRF and its allies tried again (albeit unsuccessfully this time) to pass a similar resolution in the State Duma (Reuters 2000; Uzelac 2000). With the ascent of former KGB agent and Federal Security Service head Vladimir Putin to the Russian presidency in March 2000, the fate of Dzerzhinskii's statue stood to remain contested for quite some time.

\section{Public Opinion and Elite Control of Monuments}

The quasi-democratic nature of Russia's political system means that the public has not directly and consistently participated in the official monument-building and memorialization process. In other words, it is in the interest of elites to appeal to popular opinion, but not to cede actual control over monuments and memorials. Even the most populist, apparently spontaneous actions have been strongly influenced if not coordinated by elite political interests. Luzhkov, as we have seen, took credit for removing the statue of Dzerzhinskii by channeling this "excellent thought" into concrete action. He is in fact explicit about the importance of elite control, stating that "Maybe Muscovites will remove some monuments in the future. It is possible. But this must happen by a decision 
of city authorities, and not by the will of the crowd. In general, the crowd does not have the right to dictate its decision" (Luzhkov 1996, 276).

These autocratic tendencies do not mean, however, that Luzhkov or other political leaders acted against popular opinion when they took this leading role. Although the manipulation of and conflict over monuments and memorials has taken place principally among the political elites of Russia, it has also been a struggle for popular legitimacy. Indeed, the symbolic capital of monuments and memorials depends, to one degree or another, on the recognition of the prestige and legitimacy of these sites by the general public.

This issue raises broader questions concerning the reception of these monuments by their intended audience - the Russian public. The conventional model of textual interpretation (drawn from both literary criticism and landscape studies in geography) has emphasized either the issue of authorship (the intention behind the creation of a text or interpretation), or the interpretation of texts/landscapes in and of themselves. More recent poststructuralist approaches, however, have focused new attention on the question of reception or readership (Natter and Jones 1993). From this perspective, the meaning of a text, landscape, or (in our case) monument is always polymorphous and dependent on multiply situated readers. The ability of the state or political elites to impose their intended meaning on an audience is limited by the active role readers play in the creation of meaning.

In an effort to assess the reception of places of memory in Moscow, we administered a twenty-six question (two-page) survey instrument to 501 Russians visiting the four monument sites under study. ${ }^{16}$ Our surveys revealed considerable uniformity in 
public views of various prominent monument sites in Moscow, and indicated that although Russian elites may not be directly accountable to the public in these matters, at some level their actions must resonate with the popular imagination in order for these elites to acquire symbolic capital. We asked our respondents to rank seven prominent Moscow sites and seven national holidays in order of importance (See Tables 2 and 3). As expected, places and dates that honor Russian history and culture (the Kremlin, the Tretiakov Gallery, Pushkin Square, New Year's Day, and Orthodox Christmas) and commemorate the Great Patriotic War (Victory Park and Victory Day) ranked highest. ${ }^{17}$ In other words, Luzhkov and Yeltsin successfully co-opted and glorified sites that already embodied many popular Russian symbols and sentiments. In another example, although Russian observers occasionally criticized specific aspects of the Victory Park complex during its construction, after its opening it quickly became a popular site for war veterans, school groups, military ceremonies, and bridal parties (not to mention skateboarders and picnickers). Indeed, on a single Friday afternoon in June 2001, we observed over 20 separate bridal parties at the park during a one-hour period. Victory Park came to rival the Tomb of the Unknown Soldier as a required post-wedding destination.

Table 2: Survey Ranking of Moscow Sites

\begin{tabular}{ll}
\hline Sites & Ranking \\
\hline Kremlin & 1.72 \\
Tretiakov Gallery & 2.99 \\
Victory Park & 3.62 \\
Pushkin Square & 4.24 \\
Moscow State University & 4.45 \\
Lenin's Mausoleum & 4.85 \\
The "White House" & 6.02 \\
\hline Sites ranked in order of most important (1) \\
to least important (7). N = 390 to 460. ${ }^{18}$
\end{tabular}


Table 3: Survey Ranking of Major State Holidays

\begin{tabular}{ll}
\hline Holidays & Ranking \\
\hline New Year's Day (January 1) & 1.35 \\
Victory Day (May 9) & 2.90 \\
Orthodox Christmas (January 7) & 2.95 \\
May Day (May 1) & 4.64 \\
Russian Independence Day (June 12) & 6.01 \\
Revolution Day (November 7) & 6.16 \\
Constitution Day (December 12) & 6.45 \\
\hline
\end{tabular}

Holidays ranked in order of most important (1) to least important (7). $\mathrm{N}=373$ to $481 .{ }^{19}$

Similarly, Luzhkov's unilateral decision to reconstruct the Tsarist-era Church of Christ the Savior on the site of a popular swimming pool drew surprisingly few protests, even though the city is severely under-served by such recreational facilities (Siderov 2000,561 ). Our survey revealed hearty support for the reconstruction after the fact - just over 67 percent of those surveyed either "strongly agreed" or "agreed" with the rebuilding. ${ }^{20}$ Actions such as the removal of Dzerzhinskii's statue and the reconstruction of the Church of Christ the Savior thus did more than merely express popular will or serve elite interests at the expense of the public. Rather, Luzhkov took action (and credit) after correctly "reading" popular sentiment, and in doing so, captured the symbolic capital associated with the sites. Luzhkov's occasional failure in this regard, such as the intense public displeasure evoked by his decision to erect Tsereteli's immense, unattractive statue of Peter the Great on the banks of the Moscow river, underscores the importance of readership in the accumulation of symbolic capital.

The conflict over Lenin's body and tomb during the summer of 1999 illustrates a more complex case of the intertwined relationship between political elites and popular opinion. In this instance, Yeltsin and the KPRF (and associated parties) were the 
principal players vying for control over Lenin's body. Although there were active protests at the site defending Lenin's place in the mausoleum, public opinion -- even among those visiting the body -- strongly favored burial. ${ }^{21}$ (Table 4).

Table 4

"Lenin's body should be buried." (July/August 1999)

\begin{tabular}{lccccc}
\hline & $\begin{array}{c}\text { Strongly } \\
\text { Agree }\end{array}$ & Agree & Neutral & Disagree & $\begin{array}{c}\text { Strongly } \\
\text { Disagree }\end{array}$ \\
\hline Lenin's Mausoleum $(\mathrm{n}=132)$ & $12.1 \%$ & $40.2 \%$ & $18.2 \%$ & $22.7 \%$ & $6.8 \%$ \\
All Sites $(\mathrm{n}=390)$ & $21.5 \%$ & $39.2 \%$ & $15.1 \%$ & $19.0 \%$ & $5.1 \%$ \\
\hline
\end{tabular}

A nationwide poll conducted by the Foundation for Public Opinion in early August 1999 yielded similar results, with 53 percent of respondents in Moscow and St. Petersburg actively advocating burial. This same national poll also revealed that only those individuals over 50 years old, with less than a secondary-school education, or living in rural areas of Russia rejected burying Lenin more often than they favored it. Lenin's Mausoleum remained contested despite the broad local support for burial primarily because the KPRF made it a center of symbolic resistance to both Yeltsin and Luzhkov. Although the constituencies objecting to burial were relatively far removed from the levers of power, the strong core of protesters at the site also helped to prevent any action. Yet the reasons for the standoff were perhaps more complex. The protesters provided Yeltsin and Luzhkov with a visible "threat" from the KPRF, aiding their own efforts to garner political support from anti-communists. The failure to bury the body despite Yeltsin's repeated threats and Luzhkov's enormous power in Moscow suggests that carefully managing the popular support for burial was politically more useful than actually doing it. In a sense, Yeltsin and Luzhkov used the negative symbolic capital associated with the site to cultivate their own legitimacy. 


\section{Comparative Memorialization in the Post-Soviet Era}

We have sought to demonstrate how changes to Soviet-era monuments and memorials both reflected and produced emerging forms of post-Soviet Russian identity. During this critical juncture in Russia's history, elites glorified monuments celebrating elements of Soviet identity associated with the Great Patriotic War, reweaving these events with more explicit appeals to ethnic Russian heritage and the Orthodox Church in order to recast the war as a victory for the Russian people. Monuments commemorating Lenin and the Russian Revolution had a more ambiguous status, with elites either unwilling or unable to effectively co-opt or desecrate these sites. Finally, sites celebrating the Communist Party of the Soviet Union and the command economy found little support among political elites, with even the KPRF investing its energy in protecting the status of Lenin's Mausoleum.

If nationalism involves the weaving together of historical events, characters, myths and pure fiction into a constitutive narrative of political identity, the recreation of Russian identity during this critical juncture between 1991 and 1999 involved the selective unraveling of the fabric of the Soviet "nation." Yet a number of competing "weavers" - political factions - undertook this re-creation in the style of the Tsarist and Soviet states, co-opting and building grandiose monuments that emphasized overt iconographic symbols, highlighted ethnic and imperial conceptions of Russian identity, and reinterpreted rather than rejected much of Soviet history. ${ }^{22}$ This failure to decisively break with the Soviet past during Russia's window of opportunity legitimized President Vladimir Putin's subsequent efforts to revive, rewrite, and manipulate Soviet history for his own political ends. 
After Putin's election in March 2000 and the electoral success of his affiliated Unity party in the December 1999 Duma elections, both the KPRF and Yurii Luzhkov saw their power to influence national politics fade and sought accommodation with the Putin regime. ${ }^{23}$ As a result, Putin enjoyed a freer hand in manipulating the symbolic landscape of Moscow. His first such act installed a plaque and bust dedicated to former KGB head and Soviet general secretary Yurii Andropov at the Lubianka. Later, Putin declared that Lenin, at least for the moment, would stay put on Red Square. As Putin observed, "Once I see an overwhelming majority of people wanting to tackle the Lenin question, we will discuss it. But today I don't see it and therefore we will not talk about it" (Reuters 2001).

More disturbing, though, was the symbolic renaissance that Stalin enjoyed once Putin came to power. For celebrations surrounding Victory Day 2000, Putin not only began his presidential address to veterans with the precise words Stalin had spoken in 1945, but installed a commemorative plaque at the Kremlin honoring Stalin (among others) as a war hero and authorized the Central Bank of Russia to print commemorative coins with Stalin's portrait (Traynor 2000). Not long afterwards, he approved the restoration of the Soviet national anthem as the Russian anthem, with new words venerating the Russian homeland penned by the aging author of the old. Putin even approved the installation of a bust of Stalin at Victory Park, albeit inside the museum rather than in the park itself. With this symbolic rehabilitation of Stalin, Putin found common ground with the KPRF in a mutual veneration of Soviet-style political order and military glory reinterpreted as Russian ethnic and imperial tradition. 
In many ways, the historical and geographic congruence of Russia and the USSR means that some continuity was to be expected, but it is also fair to ask what alternatives existed. Examples from the Czech Republic and Hungary suggest how radically the style of monuments and the memorialization process could change during post-communist critical junctures.

In contrast to the generally mammoth scale and intense ethnic-imperial symbolism of official post-Soviet Russian memorials, many state monuments erected in East European countries since 1989 drew their power from modesty and simplicity, and emphasized civic-democratic values. For example, a small memorial in the Czech Republic commemorates the "Velvet Revolution" of 1989. The monument hangs inconspicuously under an arcade in Prague at the site of the protest march that sparked the Velvet Revolution. It consists of a small plaque with the date ("17.11.1989") and eight hands reaching upwards, giving the split-fingered victory sign or simply showing open palms. Similarly, the new Hungarian monument to Imre Nagy (the communist leader whom the Soviets executed for his sympathetic role in the 1956 revolution) depicts an ordinary, life-sized man standing on a bronze bridge. The memorial's spatial placement, however, packs a punch. With clear sight lines, Nagy pointedly turns his back on the controversial Red Army Memorial honoring the Soviet "liberation" of Budapest in 1945, and looks toward the massive Hungarian parliament building, a failed reformer standing on a bridge between two worlds.

Similarly, Czech and Hungarian treatment of Soviet-era monuments reflects an irony missing in the Russian context. For example, the Czech government approved the installation of a giant metronome on the base of what had been the world's largest statue 
of Stalin in Prague. Boym (2001: 231) describes it as an "anti-memorial", and observes that "The rhythm of the metronome deprives time of direction ... [as] opposed to the teleological, forward-looking time of Marxist-Leninist progress toward the bright future." In another case, a group of Czech artists dealt with a particularly disliked memorial - a Soviet tank - by repeatedly painting it bright pink until the Soviets were forced to remove it out of embarrassment. In Hungary, the state moved the most prominent Soviet-era statues in Budapest to a small, specially designed park on the outskirts of the city. Unlike Moscow's Art Park, Statue Park in Budapest does not pretend that its statuary is anything but political. Rather, the park simultaneously emphasizes the statues' political character and robs them of their emotive power by clearly situating them (and their associated messages) in an anachronistic past.

The treatment of Soviet-era monuments does present different issues in Russian and non-Russian contexts, since the removal of Soviet monuments from public spaces in East Europe can be interpreted as a process of decolonization. Consequently, former Eastern-bloc countries have been able to draw on images of national identity that are unavailable to Russia. As Urban (1994) puts it, Russia lacks an "alien outsider" against which to build its national identity. Countries such as the Czech Republic, Hungary, and Poland have constructed national narratives in which their "genuine" national identities have reemerged after suppression during the Soviet period (see Dawson 1999). Indeed such "anti-imperialist" narratives have deep historical roots in the East European nations (Elster, Offe and Preuss 1998, 252-253). The symbolic response of these countries has been mirrored by their effort to seek closer ties to Western Europe (by joining NATO, the 
European Union, etc.), and by the establishment of relatively strong democratic political institutions.

For obvious reasons such strategies are more problematic for Russia, but the German experience also suggests how the memorialization process can achieve relatively drastic breaks with the past. In addition to bearing the historical legacy of the Holocaust and Nazism, Germany has undergone a process of de-Nazification, decolonization (from both the East and West), and unification. In particular, the legacies of Nazi-era ethnicimperial nationalism presented deeply troubling questions about the specific character of the German nation, the significance of history in national identity, and the role of nationalism in state building. Although the creation of German monuments after 1945 was not unproblematic, the process involved more public participation, generated extensive self-critical examination, and was highly sensitive to potential physical and symbolic continuities with the Nazi period (Till 1999). Mark Kramer (2001) suggests that Germany's efforts to come to terms with its troubled past "were vital in consolidating the democratic foundations of the new Germany," and that, in comparison, "so long as the symbols and institutions of Soviet repression are still flourishing in Russia, the prospects for democracy will be dim."

Not all memorials in Moscow replicated the monumental scale and messages of the Tsarist and Soviet traditions. For example, the monument commemorating victims of Stalinist repression, erected in a park adjacent to the former site of Dzerzhinskii's statue and to the Lubianka in October 1990, is subtle, understated and abstract (Figure 8). It consists of a single boulder from the Solovki gulag placed on a low marble platform. The stone is in an apparently precarious position, seemingly ready to tumble over on its side. 
A paragraph of text explaining the monument is etched in the horizontal surface, so that one must lean over the platform to read it. ${ }^{24}$ The entire memorial is less than two meters high. Its origin also differs from the ones we have discussed earlier because it was constructed through the efforts of Memorial, a society founded in the late 1980s dedicated to the rehabilitation and commemoration of those killed under Stalin. As such, Memorial was one of the first major independent grassroots organizations in the Soviet Union (Smith 1996, White 1995). In short, the Solovki monument is different in construction, design, and origin; its form and provocative location representing the antithesis of official, grandiose Soviet-era and contemporary Russian monuments. Organizations like Memorial and monuments like the Solovki stone may not represent the future of Russian civil society (or a permanent break with the tradition of bombastic national monuments). However, they do suggest that Russia's "cultural tool kit," while dominated by ethnic and imperial conceptions of the nation, may have contained enough equipment to build a viable civic tradition as well (Swidler 1986).

\section{Symbolic Capital and "Missing”" Monuments}

If such alternatives existed in the early 1990s, why did Russian political elites reject civic nationalism during the transformation period and draw predominantly upon ethnic and imperial traditions instead? In the optimistic atmosphere of 1991, the emergence of civic-democratic representations of the Russian nation seemed not only possible, but likely. The subsequent failure to construct monuments to democratic ideals or figures, or to the democratic Russian state itself, has been so striking that they constitute a "missing" category of civic monuments. By way of conclusion, we 
demonstrate that analyzing absent or "missing" monumental forms in terms of their symbolic capital is equally important in understanding political struggles over national identity. This absence resulted neither from elite suppression of popular democratic will nor from an inherently authoritarian political culture. Rather, like the redefinition of Soviet sites, this absence can be traced to the interaction between Soviet-era symbolic legacies and the contingent relationship of political elites with the public during the postSoviet transformation.

Just a few years into the transition, powerful political elites and the Russian public both exhibited lukewarm support, at best, for civic representations of the nation. For their part, not only did political elites express little interest in building new civic monuments, but they ignored those few that already existed. For example, neither Yeltsin nor Luzhkov preserved the trolleybus used as a barricade in front of the Russian White House during the attempted coup in 1991. The vehicle - rammed by a tank during the standoff was initially placed in front of the Museum of Contemporary History and served as a reminder of the deaths of three civilians killed during the defense (York 1998). It was a potentially powerful monument to the ideals of civic nationalism, embodying martyrdom in defense of democracy and the rule of law. By the spring of 1998, however, museum visitors and curators considered the wrecked orange trolleybus an eyesore, and it was removed from public view. Unlike many Soviet-era memorials, the functional disavowal of this potentially powerful civic symbol appeared to arise from neglect rather than design. Yet any of the glorified monuments in Moscow would have suffered the same fate without "commemorative vigilance" by political patrons. The neglect of the 
trolleybus illustrated the broader failure of civic identity to capture the elite or popular imagination.

Similarly, our surveys revealed the limited appeal of civic-democratic symbols for the Russian public. For example, our respondents ranked the site most closely associated with a civic national identity, the White House, a distant last of the seven possible choices. The White House was the seat of the elected Russian Supreme Soviet during the August 1991 coup attempt, where Yeltsin famously stood on top of a tank to defend the Union's Constitution and the Russian government. Perhaps more than any other location, it represents the place where the Soviet hold on power finally dissolved. Nonetheless, most of our respondents held it in contempt, and fewer than 20 (3.8 percent) ranked it as the first or second most important site in Moscow. Our respondents also ranked civic holidays (Constitution Day and Russian Independence Day) at the bottom of the list. Like the White House, the two civic holidays marked events that might objectively be considered foundational to post-Soviet Russia. Russian Independence Day (June 12) commemorates both the declaration of state sovereignty in 1990 and Yeltsin's election as president of Russia in $1991 .{ }^{25}$ Continuing public contempt led Yeltsin to rename it "Russia Day" in 1997 (commemorating all of Russia's history), thereby further limiting any unique significance the date might otherwise have held (Smith 1999). Another new holiday, Constitution Day (December 12), ranked last; not a single respondent ranked it first and only seven ranked it as the second most important holiday. Constitution Day held little if any symbolic capital or popular significance and illustrated the weakness associated with a civic-democratic national identity. 
As we have suggested, this outcome was not inevitable. Russia's most influential political elites and the broader public joined in rejecting symbolic expressions of civicdemocratic nationalism for three principal reasons. First, creating new symbolic capital is more difficult than glorifying or disavowing existing monuments. During critical junctures where political elites compete for public legitimacy, they act like bricoleurs, taking a pastiche of materials at hand to create a coherent narrative of tradition, memory, and history. As with all nationalist movements, historical figures and events -- and their concrete expression in monuments and memorials -- served as a basic resource for Russian political actors. Since the civic conception rejects the imperialism of Russia's past as well as ethnic definitions of the nation, political elites wanting to promote a civic identity could only draw upon the limited repertoire of the post-Soviet period. Indeed, the imperial and ethnic traditions of Russian nationalism offer powerful alternatives that are at best indifferent to democracy and constitutionalism. This need to draw on existing sources of symbolic capital helps explain how Russia moved from an apparently decisive rejection of Soviet identity in 1991 to increasingly authoritarian, Soviet-style forms of identity by 1999 . Russian elites could convert the charisma associated with certain Soviet-era monuments into ethnic and imperial national visions more easily than they could create new symbolic capital based on civic-democratic nationalism.

Second, limited participation in the memorialization process also limited the scope of possible results. Although Russia's critical juncture led to the introduction of democratic political institutions, many Soviet-era political elites retained influence in this new system and political and economic power quickly became concentrated in a relatively small group of people. This both constrained the debate over Russian national 
identity and restricted the control over public space necessary to express different conceptions of identity in monumental form. Russia's most powerful politicians would not permit the leaders of either the most politically liberal or politically nationalist parties (most of whom did not have a Soviet political background) to even enter into the competition to define and control Russian places of memory. For example, although Grigorii Yavlinskii's political party Yabloko espoused a clear civic-democratic vision for Russia and passed the electoral threshold for Duma representation in the 1993, 1995, and 1999 elections, Yeltsin and Luzhkov's physical control over Moscow made it difficult for Yabloko to impress its ideals upon the landscape. The public had even less opportunity to participate actively in this endeavor. While political transformations in many postcommunist societies loosened state control over places of memory, in Russia the restricted elite competition for control over monuments and memorials discouraged direct popular participation.

Yet if the public - the "readers" of official monuments - had expressed more enthusiasm for a civic-democratic nationalism, political elites would likely have responded by at least incorporating civic themes into existing monument sites. As we have seen, political elites are acutely aware of the public's reception and interpretation of their memorializing efforts. The tepid public response to the Yeltsin administration's tentative efforts to establish civic holidays, for example, sent political elites the message that investing in civic nationalist celebrations and sites offered them little in the way of symbolic capital. This did not reflect an inherently anti-democratic streak in Russians. Although shocked by the collapse of the USSR (and the dramatic shrinking of their state), early in the transformation period Russians often expressed strong support for many basic 
democratic ideals (Hahn 1991, Gibson et.al. 1992, Tedin 1991). As a number of

observers suggest, the public rejection of civic nationalism stemmed from the economic dislocation and poorly performing democratic political institutions in Russia after 1991 (Boym 2001, Carnaghan 2001, Tolz 1998b). In a typical statement, the director of the Museum of Contemporary History observed that "maybe if people's lives had improved after 1991, [the orange trolleybus-barricade] would have remained a symbol... But if you're not getting your wages paid, you lose interest in your ideals" (quoted in York 1998). The perceived failures of Western-inspired political democracy and economic liberalism left the Russian public with little patience for symbolic appeals to civic ideals, and many instead turned back to the Russian and Soviet pasts in their search for identity. As Boym $(2001,64)$ argues, "nostalgia became a defense mechanism against the accelerated rhythm of change and the economic shock therapy."

The ethnic-imperial expressions of Russian nationalism that came to dominate Moscow's symbolic landscape should thus be seen primarily as the result of contingent factors - competition among a small group of political elites for existing symbolic capital and public disappointment with the initial transformation process - rather than as the emergence of an "essential" Russian national identity. In particular, the concentration of control over symbolic capital affected both the process and results of memorialization in post-Soviet Russia. Civil society exercised little influence over the memorialization process, and the nation has not been represented as a democratic entity. While a window of opportunity opened slightly for civic-democratic nationalism at the beginning of the transformation period, by 1999 that window had closed. 
More broadly, our study suggests that national identity in post-communist states (and arguably in any post-authoritarian society) forms primarily during temporally and spatially limited critical junctures. By applying Bourdieu's $(1977,1990)$ concept of symbolic capital to struggles over monuments, our analysis also acknowledges the dominant role of the state (or political elites) in the memorialization process while not reducing the public to mere recipients of elite visions. The need for commemorative vigilance in creating, redefining, and maintaining monuments means that places of memory cannot be, as Levinson (1998) points out, truly "written in stone." Framing the analysis of places of memory in terms of symbolic capital makes the public's reception and readership of monuments central to the creation of meaning, and moves it beyond issues of both authorship and interpretation. As such, this characterization of conflicts over monuments, memorials, and museums during critical junctures emphasizes the dynamic process of national identity formation, in which political elites, though powerful, neither create identity free of historical and geographic constraints nor impose identity on a passive public.

\section{Notes}

${ }^{1}$ National identity in post-Soviet Russia poses an especially interesting set of questions because of the closely intertwined histories of Russia and the USSR. Indeed, the evolution of Russian national identity has attracted considerable political and scholarly concern among political scientists in the last ten years (e.g., Chafetz 1997; Dunlop 1993, 1993-94; Kommisrud and Svartdal 1992; Rousselet 1994; Tolz 1998a, 1998b; Urban 1994, 1998), but few (e.g., Smith 1996) have specifically examined the role of monuments and memorials in constructing this identity. In contrast, a number of works in 
geography and related disciplines have used monuments, memorials, and public landscapes to evaluate the process of nation-building and the formation of political communities. With the notable exceptions of Sidorov (2000) and Verdery (1999), however, they have not examined this issue in Russia. (See, for example, Atkinson and Cosgrove 1998; Foote 1997; Gillis 1994; Harvey 1979; Heffernan 1995, 1998;

Hershkovitz 1993; Johnson 1995; Koshar 1998; Leitner and Kang 1999; Till 1999; Young 1993.) Till (forthcoming) provides a summary and overview of the use of monuments and memorials for national commemorations.

${ }^{2}$ Some cultural geographers emphasize the role of material, as opposed to symbolic landscapes (Mitchell 1996). Such works argue that elites are principally concerned with the control of material resources and labor, rather than symbolic manipulation. In this view, landscapes should be interpreted in terms of the underlying processes of exploitation rather than narrowly in terms of their symbolic meanings.

${ }^{3}$ The logic of symbolic capital can exist simultaneously with the logic of market capital. In Bourdieu's study, exchanges within the "family" or immediate community are based on honor and prestige rather than on material gain, although his subjects maintain a distinct set of norms for commerce with strangers based on a more orthodox market logic. Likewise, we argue that political elites may use a logic of symbolic capital for monuments while simultaneously employing instrumental political calculation. 
${ }^{4}$ For example, although many statues of Lenin were removed and otherwise contested in Moscow and St. Petersburg, he remains standing in most smaller, provincial Russian cities, towns, and villages.

${ }^{5}$ For an explicitly geographical exploration of imperial nationalism in the Tsarist era, see Bassin (1999).

${ }^{6}$ In theoretical terms, "civic nationalism" refers more broadly to a non-ethnic, inclusive nationalism without regard for regime type (i.e., a nationalism where all citizens who share the state's ideals are considered to be members of the nation). In the Russian context, however, the inclusive Soviet-era civic-authoritarian nationalist idea based on universal adherence to the principles of Marxism-Leninism had been discredited as a state model. This left civic-democratic nationalism as the only viable, inclusive civic nationalist alternative during Russia's critical juncture.

${ }^{7}$ For example, the Moscow city government created an organization called EKOS (the Expert and Consultative Public Council), comprised of historians, artists, journalists, and other experts, to act as a "consultative body" to the city's Chief Architectural Agency. Its avowed goals, however, were unidirectional: “. . . attracting the attention of the broad public to the issues of preserving everything with historic value as a foundation for reviving national traditions" (Vinogradov 1997). EKOS's inability to protect the public interest by tempering Mayor Luzhkov's own vision for Moscow became evident in the controversy over a truly enormous, highly visible, and as a result highly unpopular statue 
to Peter the Great sculpted by Luzhkov's friend and chief artist Zurab Tsereteli. As Vinogradov puts it (in a text otherwise extremely complementary to Luzhkov and his vision, and funded by the city government itself), "Unfortunately, in spite of multiple applications to the Chief Architect of the city, EKOS was not provided with the design materials on the monument ... the absence of normal procedures of approvals and agreements on this composition, at such an important place for the Moscow city construction, leads to an ... idea that in a democratic country the end should not be justified by just any means" (215).

${ }^{8}$ In the United States there has been ongoing friction over war memorials adjacent to the Mall in Washington, DC. Conflict has centered in particular on the strip of land between the Washington Monument and the Lincoln Memorial. The construction of the Vietnam War Memorial in the early 1980s generated controversy over both the tragic, statute-less design, and its placement so close to monuments glorifying American history and democracy. More recently, the decision to build a memorial to the Second World War directly on the Mall has sparked artistic, political, and legal fights, with each side claiming that the site is too important and sacred to include or to not include this monument.

${ }^{9}$ These celebrations often were centered around Pushkin Square or other sites associated with Pushkin, while Luzhkov actually erected a new monument to Pushkin in central Moscow just off Tverskaia street. Indeed, for a few weeks in the summer of 1999 
Luzhkov saturated Moscow with Pushkin's image and with banners proclaiming wellknown Pushkin verses.

${ }^{10}$ The caption underneath a large color photograph of Luzhkov and Aleksei II (the Patriarch of the Russian Orthodox Church) at the cathedral in one of the commemorative books produced for the anniversary celebration made it clear who deserved credit for the work: "Moscow mayor Yurii Luzhkov took the responsibility for the reconstruction of the Church of Christ the Savior upon himself. Patriarch Aleksei II blessed the construction workers" (Zhigailov 1996: 12).

${ }^{11}$ The official resolution to erect a monument on Poklonnaia gora, "O sooruzhenii pamiatnika Pobedy v g. Moskve," was approved by the Presidium of the CPSU Central Committee on May 31, 1957.

12 This led to a symbolic disjuncture between the park and the museum, since the museum's design and collection had been created earlier (and because Luzhkov and the Moscow city government had little control over the museum itself, in contrast to the park surrounding it). For example, the ceiling in the museum's Hall of Glory is lit by a chandelier in the shape of a star, and the Hall's central figure is a massive, Soviet-style male statue. 
13 The foundation charged with preserving Lenin's remains, the Scientific Research Center of Biological Structures still advocates its mission in "scientific" terms (The Guardian 1999).

${ }^{14}$ Luzhkov's own account suggests that the statue of Lenin in October Square remained untouched because the cranes reached the square late at night after the crowd had dispersed. (Luzhkov 1996: 272-276). “Then I decided to leave it standing. And I am sure that I did the right thing. All of these monuments - they are a part of our history. . . I am against rewriting history."

${ }^{15}$ Only the display surrounding Stalin's statue had obvious political symbolism, and it is clearly an unusual case. Unlike the other Soviet-era statues, the Stalin statue was dismantled well before 1991. Like other statues of Stalin in Russia, it was removed from public display during the de-Stalinization process under Khrushchev, and had reportedly been buried in the sculptor's garden until it was "resuscitated" and placed in the park in 1991 (Boym 2001). In 1998 the artist Evgenii Chubarov donated a sculpture group symbolizing the gulag to Art Park, which was erected surrounding Stalin. A three-meter wall formed of crudely rendered stone heads behind lines of barbed wire framed the Stalin statue, which then faced a one-meter high triangular pile of heads in the same style. Other "gulag" figures by the same artist were added later. Although we found the symbolism rather powerful and effective, when we interviewed several sculptors working in the park, they dismissed the display as that of an "amateur" artist who did not deserve the recognition accorded to professionals. 
${ }^{16}$ We had initially expected to find variations in the responses of visitors among the different sites (reflecting the attraction of different types of monuments to different groups), but in practice we found few significant variations. The surveys contained basic demographic questions (including sex, age, place of birth, nationality, education and occupation), several structured questions to assess the frequency and purpose of the respondent's visit (including a final, open-ended question, "Why did you come here today?"), and questions to measure political party and religious affiliation. We also asked our subjects to respond ("Strongly Agree"; "Agree"; "Neutral”; "Disagree”; "Strongly Disagree") to six statements regarding contemporary political and social developments to measure political attitudes and nationalistic sentiments. We conducted the survey on three separate days (including at least one Saturday or Sunday) at each of our three primary study sites and also administered the survey at Art Park on one weekday as a control. We instructed our administrators to approach visitors at random using various techniques (e.g., asking every third or fifth person; using random walks, etc.), and to only solicit responses from Russian citizens. At least one of the authors remained in the area unobtrusively to ensure that the administrators followed the appropriate technique and to answer any questions that arose during the process. We spot-checked the representativeness of our samples by independently calculating the gender ratio of visitors and comparing it to the ratio in the surveys. (There were no significance differences.) It is difficult to estimate the sample proportion at the different sites, although we were able to do so at the Lenin Mausoleum (2.4\%) on one of our sample days by counting the number of visitors entering the line $(\sim 3500)$ during the three-hour 
survey period. The sample size was slightly smaller at Victory Park and the former VDNKh, and considerably larger (perhaps 80\%) at Art Park. The refusal rate was similar at the four sites, generally below $20 \%$, although it was somewhat higher for particular questions. Our survey administrators thought that most of those who refused simply did not want to take the time to complete the form. Copies of the original survey instrument can be obtained from the authors.

${ }^{17}$ The most popular holiday, New Year's Day, does not hold any particular religious or political significance. Like the Lenin Mausoleum, the low-ranked Revolution Day marks the October Revolution of 1917 and is therefore a contested commemoration. A poll of 1600 Russians by the All-Russian Center for the Study of Public Opinion on the eve of November 7,1998 , revealed that only $39 \%$ considered the date to be a holiday. The holiday, however, had more significance for older Russians: those over 55 were four times more likely to express that opinion than those under 25 (Interfax 1998). Yeltsin attempted unsuccessfully to recast Revolution Day in more civic terms by renaming it the "Day of Reconciliation and Accord."

${ }^{18}$ Rank order did not change when we limited the sample to Moscow residents $(\mathrm{N}=232)$, and the only notable difference was the relatively lower score Moscow residents gave to Lenin's Mausoleum (5.23). Similarly, rank order varied by survey site in only one instance: visitors to Lenin's Mausoleum ranked it fourth (3.76) while respondents at all other sites ranked it sixth (but still well ahead of the White House). 
${ }^{19}$ Many respondents to this question did not rank all seven holidays, typically responding instead in what we came to call the "1-2-3 go-to-hell" pattern. These respondents ranked New Year's Day, Victory Day, and Christmas Day (and sometimes May Day), while giving $7 \mathrm{~s}$ to the rest of the holidays or leaving them blank. Using only "correct" responses (i.e., those 142 respondents who consecutively ranked all holidays) does not change the rank ordering of these "rejected" holidays, but it does raise their respective scores slightly (May Day $=3.96$, Independence Day $=5.34$, Revolution Day $=5.85$, and Constitution Day $=6.11$ ).

${ }^{20}$ Moscow residents did express slightly more negative opinions toward the rebuilding effort: only $64 \%$ approved while $21 \%$ disapproved. It is possible that relatively more Muscovites would have preferred the pool over the church, or it may represent local resentment against Luzhkov. In either case, it suggests how nonlocal residents may view "local" monumentalization efforts in a more positive light.

${ }^{21}$ Interestingly, many of the respondents favoring burial told our surveyors that it was "un-Christian" to leave the body unburied, and that being displayed in the mausoleum was contrary to Lenin's own wishes.

${ }^{22}$ As one Russian observer noted, in glorifying the Russian past Moscow mayor "Yurii Luzhkov hasn't come up with any new principle. He follows the same path that Stalin did during the critical situation in the war . . exactly in that moment, all the history of Russia became the history of the USSR" (Borisov 1999: 43). 
${ }^{23}$ In a direct affront to Luzhkov's power to control public space, in March 2001 the Putin administration's Ministry of Culture and Ministry of Property both declared that sites with "federal significance" in Moscow should be transferred from local to federal control by December, an order that Luzhkov vigorously fought (Clark 2001, Kabanova 2001, Polinin and Anisimov 2001).

${ }^{24}$ It says "The society 'Memorial' was especially nominated to provide this stone from the territory of the Solovetskii camp and to erect it in memory of the millions of victims of the totalitarian regime. 30 October 1990." The faint inscription on the stone's pedestal forces visitors to come close to the stone and look very carefully to read the words.

${ }^{25}$ It had been celebrated as a holiday since 1991, and declared an official state holiday in 1994 despite significant objections from the KPRF and others who considered it a day celebrating Yeltsin's personal triumph rather than Russian independence. 


\section{References}

Agence France Presse. 1999. “Lenin Is a 'Religion' for the Masses: Seleznyov.” June 1.

Anderson, Benedict. 1983. Imagined Communities: Reflections on the Origin and Spread of Nationalism. London: Verso.

Atkinson, D. and Denis Cosgrove. 1998. "Urban Rhetoric and Embodied Identities: City, Nation, and Empire at the Vittorio Emanuele II Monument in Rome, 1870-1945." Annals of the Association of American Geographers 88 (1): 28-49.

Barnard, Anne. 1994. "Space Park To Mall: A Giant Leap." Moscow Times. October 13.

Bassin, Mark. 1999. Imperial Visions: Nationalist Imagination and Geographical Expansion in the Russian Far East, 1840-1865. Cambridge, U.K.: Cambridge University Press.

Bonnell, Victoria. 1997. The Iconography of Power: Soviet Political Posters Under Lenin and Stalin. Berkeley: University of California Press.

Borisov, Pavel, 1999. "Proshlyi vek luzhkovskoi arkhitektury.” Kommersant vlast 30(331): 4043.

Borodina, Evgeniia. 1999. “Interv'iu.” Metro. July 20.

Bourdieu, Pierre. 1977. Outline of a Theory of Practice. Cambridge: Cambridge University Press.

---- 1990. The Logic of Practice. Stanford: Stanford University Press.

Boym, Svetlana. 2001. The Future of Nostalgia. New York: Basic Books.

Carnaghan, Ellen. 2001. “Thinking About Democracy: Interviews with Russian Citizens.” Slavic Review 60 (2): 336-366.

Chafetz, Glenn. 1997. "The Struggle for a National Identity in Post-Soviet Russia." Political Science Quarterly 111 (4): 661-688. 
Clark, Torrey. 2001. "Moscow Battles to Keep Monuments.” Moscow Times, May 29.

Cohen, Stephen F. 2000. Failed Crusade: America and the Tragedy of Post-Communist Russia. New York: Norton.

Collier, Ruth Berins and David Collier. 1991. Shaping the Political Arena: Critical Junctures, The Labor Movement, and Regime Dynamics in Latin America. Princeton: Princeton University Press.

Cosgrove, Denis. 1998 (1984). Social Formation and Symbolic Landscape. Madison: University of Wisconsin Press.

Cosgrove, Denis and Stephen Daniels, editors. 1988. The Iconography of Landscape: Essays on the Symbolic Representation, Design, and Use of Past Environments. New York: Cambridge University Press.

Dawson, Andrew H. 1999. "From Glittering Icon to...” The Geographic Journal 165 (2): 154160.

Dovey, K. 1992. “Corporate Towers and Symbolic Capital.” Environment and Planning B: Planning and Design 19(2): 173-188.

Duncan, James. 1990. The City as Text: The Politics of Landscape Interpretation in the Kandyan Kingdom. New York: Cambridge University Press.

Duncan, James and Nancy Duncan. 1988. "(Re)reading the Landscape." Society and Space 6: 117-126.

Dunlop, John. 1993. The Rise of Russia and the Fall of the Soviet Empire. Princeton: Princeton University Press.

---- 1993-94. “Russia: Confronting a Loss of Empire, 1987-1991.” Political Science Quarterly 108(4): 603-634. 
Elster, Jon, Claus Offe, and Ulrich K. Preuss. 1998. Institutional Design in Post-communist Societies: Rebuilding the Ship at Sea. Cambridge: Cambridge University Press.

Foote, Kenneth E. 1997. Shadowed Ground: America's Landscapes of Violence and Tragedy. Austin: University of Texas Press.

Gellner, Ernest. 1983. Nations and Nationalism. Ithaca: Cornell University Press.

Gibson, James L., Raymond M. Duch, and Kent L. Tedin. 1992. "Democratic Values and the Transformation of the Soviet Union.” Journal of Politics 54:329-371.

Gillis, John R., editor. 1994. Commemorations: The Politics of National Identity. Princeton: Princeton University Press.

Glushchenko, A. 1990. “Kakoi byt' VDNKh?” Za peredovoi opyt 38(3774), October 17.

The Guardian. 1999. “One Foot in the Grave.” July 28.

Hahn, Jeffrey W. 1991. “Continuity and Chnage in Russian Political Culture.” British Journal of Political Science 21: 393-441.

Harrison. S. 1995. "Four Types of Symbolic Conflict.” Journal of The Royal Anthropological Institute 1(2): 255-272.

Harvey, David. 1979. "Monument and Myth." Annals of the Association of American Geographers 69 (3): 362-381.

Hearst, David. 1999. “Lenin To Be Buried At Last.” The Guardian. August 4.

Heffernan, Michael. 1995. "For Ever England: the Western Front and the Politics of

Remembrance in Britain.” Ecumene 2: 293-324.

----- 1998. The Meaning of Europe: Geography and Geopolitics. New York: Oxford University Press. 
Henry, Patrick. 1996. "Whither Russia? Answers on a Postcard, Please." Moscow Times. August 1.

Hershkovtiz, Linda. 1993. "Tiananmen Square and the Politics of Place.” Political Geography 12 (5): 395-420.

Hobsbawm, Eric J. 1990. Nations and Nationalism since 1780: Programme, Myth, Reality. New York: Cambridge University Press.

Il'in, S.B. 1986. Vsenarodnaia akademiia. Moscow: Politizdat.

Interfax, 1998. "For Half of Russia's Citizens, Nov. 7 is Just Another Day Off." Novye izvestiia, November 5. Trans. in Current Digest of the Post-Soviet Press 50:44 (1998).

Johnson, Juliet. 2001. "Path Contingency in Postcommunist Transformations." Comparative Politics (33:3): 253-274.

----- 2000. A Fistful of Rubles: The Rise and Fall of the Russian Banking System. Ithaca: Cornell University Press.

Johnson, Nuala. 1995. "Cast in Stone: Monuments, Geography and Nationalism." Society and Space 13 (1): 51-65.

Kabanova, Ol'ga. 2001. 'Mikhail Shvydkoi: Den'gi ot arendy pamiatnikov dolzhny idti na ikh soderzhanie.” Izvestiia, June 4.

Kaiser, Robert J. 1994. The Geography of Nationalism in Russia and the USSR. Princeton: Princeton University Press.

Kinzhalov, Emil'. 1999. Head of Scientific Analysis for the Exposition, Museum of the Great Patriotic War, personal interview, August 6, Moscow. 
Kommisrud, A. and H. Svartdal. 1992. "Back To The Future: State-Building and National Myths in the Russian Historical Tradition." Internasjonal Politikk 50(1-2): 79-93.

Korotkaia, Elena. 1999. "VVTs - Vchera, segodnia, zavtra," Torgovo-nromyshlennye vedemosti, June 16-30.

Kramer, Mark. 2001. "Why Soviet History Matters in Russia.” PONARS Policy Memo 183.

Krasnaia zvezda. 1958. "Praznovanie v Moskve” 47(10430), February 25.

Krasner, Stephen. 1984. “Approaches to the State,” Comparative Politics (16:2): 223-246.

Leitner, Helga and Peter Kang. 1999. "Contested Urban Landscapes of Nationalism: The Case of Taipei." Ecumene 6 (2): 214-233.

Levinson, Sanford. 1998. Written in Stone: Public Monuments in Changing Societies. Durham and London: Duke University Press.

Levi-Strauss, Claude. 1966. The Savage Mind. Chicago: University of Chicago Press.

Luzhkov, Yurii. 1996. My Deti Tvoi, Moskva. Moscow: Bagrius.

McCann, E. J. 1995. "Neotraditional Developments: The Anatomy of a New Urban Form.” Urban Geography 16(3): 210-233.

Miliutenko, Vladimir. 1999. Mer v Kepke. Moscow: MNEPU.

Mitchell, Don. 1996. The Lie of the Land: Migrant Workers and the California Landscape. Minneapolis: University of Minnesota Press.

Moskovskaia pravda. 1987. "Ob itogakh vsesoiuznogo otkrytogo konkursa na luchshii proekt monumenta pamiatnika pobedy na Poklonnoi gore v Moskve.” February 22.

Moscow Times. 1999. "Vets Celebrate V-Day, Remember Serbs.” May 11.

Natter, Wolfgang and John Paul Jones. 1993. "Signposts Toward a Poststructuralist Geography," Postmodern Contentions: Epochs, Politics, Space. New York: The Guilford Press. 
Nora, Pierre. 1992. "Between Memory and History," Realms of Memory: Rethinking the French Past, Volume 1: Conflicts and Divisions. New York: Columbia University Press.

Pestereva, Olga. 1998. "Yurii Luzhkov makes dreams of Jews worldwide come true." Kommersant Daily. September 3.

Poliatykin, M.A. 1996. Yurii Luzhkov: Khronologiia uspekha. Moscow: Tverskaia 13.

Polinin, Mikhail, and Gennadi Anisimov. 2001. “Oleg Tolkachev: Pamiatniki dolzhny prinadlezhat' tomu, kto vkladyvaet v nikh den'gi.” Izvestiia, June 2001.

Reddaway, Peter and Dmitri Glinski. 2000. Tragedy of Russia's Reforms: Market Bolshevism Against Democracy. Washington, D.C.: United States Institute of Peace.

Reuters. 2001. "Putin Says Lenin's Corpse to Stay Put, For Now.” July 16.

Reuters. 2000. "Russian Duma Says No to Secret Police Monument.” July 7.

Rousselet, K. 1994. "Anomy, Search for Identity and Religion in Russia." Social Compass 41 (1): $137-150$.

Russia Journal. 1999. “Park Pobedy: Long in Coming, Big on Debate.” 15 (15), May 10.

Shmidt, C.O., editor. 1998. Moskva Entsiklopediia. Moscow: Bol'shaia Rossiiskaia Entsiklopediia.

Shulyakovskaya, Natalya. 1999. "Pushkin Is Everyone's Favorite Political Tool.” Moscow Times, June 3.

Sidorov, Dmitri. 2000. "National Monumentalization and the Politics of Scale: The Resurrections of the Cathedral of Christ the Savior in Moscow." Annals of the Association of American Geographers 90(3): 548-572.

Smith, Graham. 1999. The Post-Soviet States: Mapping the Politics of Transition. London: Arnold. 
Smith, Kathleen. 1996. Remembering Stalin's Victims: Popular Memory and the End of the USSR. Ithaca and London: Cornell University Press.

----- 1999. "Inventing Holidays in the New Russia: Holidays and National Identity." Kennan Institute public lecture, March 8.

Solnick, Steven L. 1998. Stealing the State: Control and Collapse in Soviet Institutions. Cambridge, Mass.: Harvard University Press.

Sovet directorov GAO VVTs. 1999. Kontseptsiia razvitiia GAO VVTs. Protokol \#3, May 26.

Stark, David and Laszlo Bruszt. 1998. Postsocialist Pathways: Transforming Politics and Property in East Central Europe. Cambridge, UK: Cambridge University Press.

Suny, Ronald Grigor. 1999. "Provisional Stabilities: The Politics of Identities in Post-Soviet Eurasia.” Manuscript.

Swidler, Ann. 1986. "Culture in Action: Symbols and Strategies." American Sociological Review 51: 273-286.

Tedin, Kent L. 1991. "Popular Support for Competitive Elections in the Soviet Union.” Comparative Political Studies 27: 241-271.

Till, Karen. 1999. "Staging the Past: Landscape Designs, Cultural Identity, and Erinnerungspolitik at Berlin's Neue Wache." Ecumene 6 (3).

----- Forthcoming. "Places of Memory," in Companion to Political Geography, edited by John Agnew, Katherine Mitchell, and Gearóid Ó'Tuathail. London: Blackwell.

Tolstikhina, Aleksandra. 1998. “They’re Ready for Restoration! - State Duma Moves to Return 'Iron Felix' to his Pedestal.” December 3. Trans. in Current Digest of the Post-Soviet Press 50:48(1998). 
Tolz, Vera. 1998a. "Forging the Nation: National Identity and Nation Building in PostCommunist Russia." Europe-Asia Studies 50 (6): 993-1022.

----- 1998b. "Creating A Russian Nation." Perspective 9(2).

Traynor, Ian. 2000. "Russia's New Strongman Puts Stalin Back on a Pedestal.” The Guardian. May 13.

Tumarkin, Nina. 1997. Lenin Lives! The Lenin Cult in Soviet Russia. Cambridge: Harvard University Press.

---- 1994. The Living and the Dead: The Rise and Fall of the Cult of World War II in Russia. New York: Basic Books.

Urban, Michael. 1998. "Remythologising the Russian State." Europe-Asia Studies 50 (6): 969992.

----- 1994. “The Politics of Identity in Russia's Post-Communist Transition.” Slavic Review 53(3).

Uzelac, Ana. 2000. “No Lubyanka Return for NKVD Founder.” Moscow Times. July 8. Van der Heijden, Marien, editor. 1998. Museums in Revolution: Four Historical Museums in Moscow. Amsterdam: IISG Publishers.

Verdery, Katherine. 1999. The Political Lives of Dead Bodies: Reburial and Postsocialist Change. New York: Columbia University Press.

Vinogradov, V.A., editor. 1997. Moskva 850 Let, Tom II. Moscow: AO Moscow Textbooks. White, Anne. 1995. "The Memorial Society in the Russian Provinces." Europe-Asia Studies 47(8): 1343-1366.

Withers, Charles W. J. 1996. "Place, Memory, Monument: Memorializing the Past in Contemporary Highland Scotland." Ecumene 3 (3): 325-344. 
Yablokova, Oksana. 1998. "Duma Tries to Resurrect Soviet Icons." Moscow Times. December 5. Young, James E. 1993. The Texture of Memory: Holocaust Memorials and Meaning. New Haven: Yale University Press.

York, Geoffrey. 1998. "Symbols of Democracy." The Globe and Mail. November 28.

Zhigailov, Eduard. 1996. Moskva 850. Moscow: AOZT Komsomolskaia pravda. 